\title{
EFFECT OF SOIL AND FOLIAR APPLICATION OF HUMIC ACID ON GROWTH AND PRODUCTIVITY OF SOYBEAN PLANTS GROWN ON A CALCAREOUS SOIL UNDER DIFFERENT LEVELS OF MINERAL FERTILIZERS \\ Mahmoud, M. M. ; A. H. A. Hassanein; S. F. Mansour and
} A. M. Khalefa

Soil, Water \& Environ. Res. Inst., Agric. Res. Center, Giza, Egypt.

\begin{abstract}
A field experiment was carried out on a calcareous soil at Abou massou village (48 km south-west to Alexandria) to determine the effect of humic acid (HA) at the rates of 0 , soil application of (15 kg HA / fed and $30 \mathrm{~kg} \mathrm{HA} / \mathrm{fed})$, foliar spray of $0.1 \%$ $\mathrm{HA}$ and mixture of $(15 \mathrm{~kg} \mathrm{HA} / \mathrm{fed}$ as soil application $+0.1 \% \mathrm{HA}$ as foliar spray along with mineral fertilizers (MF) at the rates of 0,75 and $100 \%$ of the recommended dose of N, P and K (RDF) on some physical and chemical properties of the studied soil as well as soybean yield and its components.

The obtained results indicated that soil application of HA significantly increased soil organic matter content and positively affected bulk density and total porosity (decrease bulk density and increase total porosity). Available N, P and K in soil showed pronounced increases due to the soil application of $\mathrm{HA}$ and/ or MF, with a superiority for the treatment of $30 \mathrm{Kg} \mathrm{HA}+100 \%$ RDF over the other treatments. Growth traits , N, P and K content in seeds as well as seed yield and yield components of Soybean considerably increased as a result of soil or foliar application of $\mathrm{HA}$ and/ or MF and the increase progressed with increasing the rate of $\mathrm{HA}$ (From $15 \mathrm{~kg} \mathrm{HA}$ to $30 \mathrm{~kg} \mathrm{HA} / \mathrm{Fed}$ ) or MF (From 75 to $100 \%$ RDF). The combined application of $\mathrm{HA}$ and MF was more prominent in enhancing the aforementioned parameters compared to the treatments received solely application of MF. In this respect, the highest values of these parameters were produced by the combined application of 30 $\mathrm{kg} \mathrm{HA} /$ fed with $100 \%$ RDF.
\end{abstract}

Keywords: Humic acid, mineral fertilizers, soil properties, plant growth, Soybean.

\section{INTRODUCTION}

Humic substances (humic and fulvic acids) are the major component of soil organic matter and the term of "humus" is widely accepted as synonymous for the soil organic matter (Chen. and Aviad, 1990). The humic substances in the soil have multiple affects that can greatly benefit plants growth (Lobartini et al., 1997 ; Nardi et al., 2002 and Sangeetha et al., 2006). Many investigators classified the beneficial effects of humic acids on plant growth into direct and indirect effects. Indirect effects involve improvement of the soil properties such as aggregation, aeration, permeability, water holding capacity, micronutrients transport and availability (Tan, 2003). Direct effects are those which require uptake of humic substances into the plant tissue resulting in various biochemical effects (Chen and Aviad, 1990 and Nardi et al., 2002). Humic substances affect the solubility of many nutrient elements by building complex forms or chelating agents of humic matter with metallic cations ( Lobartini et al.,1997). 
In many studies, humic acids have been found to affect biological activity and soil properties ( Soong,1980 and Tajuddin, 1992), decrease the loss of moisture and enhance the water retention (Cheng et al.,1998), decrease soil bulk density and increases total porosity and soil organic matter content ( Salib et al., 2003 and zaky et al.,2006).

Humic acids plays a major role in plant nutrients uptake and growth parameters in plant in both vegetative and genetative stages (Ulukan, 2008) on wheat and Shehata and EL-Helaly ( 2010 ) on snap bean .

The increment of growth parameters and crop yields due to HA application may be attributed to that HA is an important component since it constitutes a stable fraction of carbon, thus regulating the carbon cycle and release of nutrients, including nitrogen, phosphorus, and sulfur, which decreasing the need for inorganic fertilizer for plant growth. HAs stimulate plant growth by the assimilation of major and minor elements, enzyme activation and/or inhibition, changes in membrane permeability, protein synthesis and finally the activation of biomass production (Ulukan, 2008). Moreover, Russo and Berlyn (1990) reported that, humates (granular and liquid forms) can reduce plant stress that involved plant diseases as well as enhance plant nutrient uptake. In addition, HA can be used as a growth regulator by regulate endogenous hormone levels (Frgbenro and Agboola, 1993 and Piccolo et al., 1992).

El-Ghamry et al. (2009) reported that all morphological characteristics, yield components, macronutrients content as well as chlorophyll content of faba bean significantly increased by foliar application of humic acid. Humic acid applied to wheat in a calcareous soil as soil application (1 and $2 \mathrm{~g} / \mathrm{Kg}$ soil) and foliar spray ( 0.1 and $0.2 \%$ ) had a significant positive effect on dry weight and NPK uptake of wheat (Katkat el at., 2009).

The enhancing effect of humic acids was also observed on the dry matter yield of corn and oat seedling (Albuzio et al., 1994 and Khaled and Fawy, 2011). Moreover, the effect of humic acids on numerous plants such as tomato (Padem an Ocal, 1999), strawberry (Neri et al., 2002), spinach (Ayas and Gulser, 2005) and bean (Zaky et al., 2006) have been well documented.

The mechanism of humic acids in promoting plant growth is not completely known, but several explanations proposed. Nardi et al. (2002) attributed the beneficial effect of humic acid on plant growth to the increasing cell membrane, oxygen uptake, respiration and photosynthesis, nutrients uptake, root and cell elongation and ion transport. Moreover, Nardi et al. (1999) mentioned that the positive effect of humic acids on plant growth may be due to its acting as plant growth hormones.

The purpose of this work aimed to determine the effect of soil and foliar application of humic acid along with different levels of mineral fertilizers on macronutrients content, Soybean yield and its component as well as macronutrients availability in soil. 


\section{MATERIALS AND METHODS}

A field experiment was carried out during the summer season of 2009 on a calcareous soil at Abou Masooud farm (48 Km south-west to Alexandria) Alexandria Governorate, Egypt. Some physical and chemical properties of the studied soil are presented in Table (1).

Table (1): Some physical and chemical properties of the soil under investigation.

\begin{tabular}{|c|c|c|c|}
\hline \multicolumn{2}{|c|}{ Practicle size distribution in presence of $\mathrm{CaCO}_{3}$} & \multirow[b]{2}{*}{$E C_{e}(d S / m)$} & \multirow[b]{2}{*}{2.36} \\
\hline$(\%)$ & 15.2 & & \\
\hline (\%) & 20.7 & \multicolumn{2}{|c|}{ Cations meq/L : } \\
\hline Fine sand & 43.2 & $\mathrm{Ca}^{2+}$ & 7.88 \\
\hline Coarse sand & 20.9 & $\mathrm{Mg}^{2+}$ & 4.85 \\
\hline \multicolumn{2}{|c|}{ Textural class : Sandy clay loam } & $\mathrm{Na}^{+}$ & 10.4 \\
\hline Bulk density $\left(\mathrm{g} / \mathrm{cm}^{3}\right)$ & 1.40 & $\mathbf{K}^{+}$ & $\overline{0.73}$ \\
\hline Total porosity (\%) & 47.2 & \multicolumn{2}{|c|}{ Anions meq /L : } \\
\hline $\mathrm{CaCO}_{3}$ & 33.4 & $\mathrm{CO}_{3}{ }^{2-}$ & 0.00 \\
\hline O.M. & 1.09 & $\mathrm{HCO}_{3}^{-}$ & 5.82 \\
\hline $\mathrm{pH}(1-2.5$ susp.) & 8.15 & $\mathrm{Cl}^{-}$ & 7.24 \\
\hline \multicolumn{2}{|l|}{ Available macronutrients } & $\mathrm{SO}_{4}{ }^{2-}$ & 10.8 \\
\hline Available $\mathrm{N}$ mg/kg soil & 64.0 & & \\
\hline Available $P \quad \mathrm{mg} / \mathrm{kg}$ soil & 10.7 & & \\
\hline Available $\mathrm{K} \mathrm{mg/kg} \mathrm{soil}$ & 315 & & \\
\hline
\end{tabular}

Soybean grains variety Giza 35 were sown in plots with $10.5 \mathrm{~m}^{2}$ in area $(3 \times 3.5 \mathrm{~m})$. The experiment was designed in a split plot design with three replicates. The treatments included three levels of mineral fertilizers, i.e. 0 , $75 \%$ and $100 \%$ of the recommended dose of $\mathrm{N}, \mathrm{P}$ and $\mathrm{K}$ in the form of ammonium sulphate $(20.5 \% \mathrm{~N})$, superphosphate $\left(15.5 \% \mathrm{P}_{2} \mathrm{O}_{5}\right)$ and potassium sulphate $\left(48 \% \mathrm{~K}_{2} \mathrm{O}\right)$ respectively. While humic acid $(\mathrm{HA})$ was applied in five levels, i.e., 0 (no humic acid), soil application of (15 kg HA/fed and $30 \mathrm{~kg} \mathrm{HA} / \mathrm{fed}$ ), foliar spray of $0.1 \% \mathrm{HA}$ and mixture of $15 \mathrm{~kg} \mathrm{HA} / \mathrm{fed}$ as soil application $+0.1 \% \mathrm{HA}$ as foliar application.

Soil application of humic acid was applied in one dose before sowing and foliar spray was done on 30, 45 and 60 days after sowing. All the agricultural recommended practices were followed as usual including the irrigation processes.

Yield and its components:

At harvest (120 days after sowing), number of pods/plant, 100 seeds weight $(\mathrm{g})$ and seed yield $(\mathrm{kg} / \mathrm{fed}$ ) were recorded. Samples of soybean seeds were digested using $\mathrm{H}_{2} \mathrm{SO}_{4}$ and $\mathrm{H}_{2} \mathrm{O}_{2}$. Total nitrogen was determined using the standard procedure of micro-kjeldahl as described by black (1965). Total phosphorus and potassium were determined according to Jackson (1973).

Soil analysis:

Soil samples were collected from all experimental plots after 70 days from sowing. Organic matter content was determined by the Walkey and 
Black method (Black, 1965). Available N, P and K in soil were determined according to Jackson (1973).

Statistical analysis:

All obtained data were statistically analyzed and compared by using least significant differences (L.S.D) according to the procedure described by Gomez and Gomez (1984).

\section{RESULTS AND DISCUSSION}

Organic matter content, bulk density and total porosity:

Organic matter content as affected by the application of humic acid (HA) and mineral fertilizers is presented in Table (2), data showed that organic matter was significantly increased upon the soil application of $\mathrm{HA}$ and progressed with increasing its rate from 15 to $30 \mathrm{~kg} \mathrm{HA} / \mathrm{fed}$. Otherwise, no significant changes were observed in organic matter content due to the foliar application of HA and / or mineral fertilizers alone. These results are in agreement with those of Zaky et al. (2006).

Table (2): Some soil properties as affected by humic acid and NPK fertilizers.

\begin{tabular}{|c|c|c|c|c|c|c|c|c|c|c|c|c|c|}
\hline \multirow{3}{*}{\multicolumn{2}{|c|}{\begin{tabular}{|l|} 
Treatments \\
(A) \\
Humic acid \\
\end{tabular}}} & \multicolumn{12}{|c|}{ (B) Fertilizer levels (\% recommended dose of NPK) } \\
\hline & & \multicolumn{4}{|c|}{ Organic matter (\%) } & \multicolumn{4}{|c|}{ Bulk density $\left(\mathrm{g} / \mathrm{cm}^{3}\right)$} & \multicolumn{4}{|c|}{ Total porosity (\%) } \\
\hline & & 0 & 75 & 100 & Mean & 0 & 75 & 100 & Mean & 0 & 75 & 100 & Mean \\
\hline \multicolumn{2}{|c|}{$\mathrm{H}_{0}$} & 0.98 & 1.01 & 1.02 & 1.00 & 1.38 & 1.35 & 1.35 & 1.36 & $47 . .9$ & 49.1 & 49.1 & 48.7 \\
\hline \multicolumn{2}{|c|}{$\mathrm{H}_{1}$} & 1.10 & 1.13 & 1.13 & 1.12 & 1.30 & 1.27 & 1.26 & 1.28 & $50 . .9$ & 52.1 & 52.5 & 51.8 \\
\hline \multicolumn{2}{|c|}{$\mathrm{H}_{2}$} & 1.17 & 1.20 & 1.21 & 1.19 & 1.23 & 1.21 & 1.21 & 1.22 & 53.6 & 54.3 & 54.3 & 54.1 \\
\hline \multicolumn{2}{|c|}{$\mathrm{H}_{3}$} & 1.01 & 1.04 & 1.03 & 1.03 & 1.35 & 1.33 & 1.33 & 1.34 & 49.1 & 49.8 & 49.8 & 49.6 \\
\hline \multicolumn{2}{|c|}{$\mathrm{H}_{4}$} & 1.12 & 1.15 & 1.15 & 1.14 & 1.28 & 1.25 & 1.24 & 1.26 & 51.7 & 52.8 & 53.2 & 52.6 \\
\hline \multicolumn{2}{|c|}{ Mean } & 1.08 & 1.11 & 1.11 & & 1.31 & 1.28 & 1.28 & & 50.6 & 51.6 & 51.8 & \\
\hline \multirow{3}{*}{ LSD $_{0.05}$} & $A$ & \multicolumn{4}{|c|}{0.08} & \multicolumn{4}{|c|}{0.06} & \multicolumn{4}{|c|}{2.25} \\
\hline & $B$ & \multicolumn{4}{|c|}{ N.S } & \multicolumn{4}{|c|}{ N.S } & \multicolumn{4}{|c|}{ N.S } \\
\hline & $A \times B$ & \multicolumn{4}{|c|}{ N.S } & \multicolumn{4}{|c|}{ N.S } & \multicolumn{4}{|c|}{ N.S } \\
\hline
\end{tabular}

$\mathrm{H}_{0}$ : No humic acid (HA)

$\mathrm{H}_{1}$ :Soil application of $\mathrm{HA}(15 \mathrm{~kg} / \mathrm{Fed})$

$\mathrm{H}_{2}$ :Soil application of $\mathrm{HA}(\mathbf{3 0} \mathrm{kg} / \mathrm{Fed})$

$\mathrm{H}_{3}$ :Foliar spray of $0.1 \% \mathrm{HA}$

$\mathrm{H}_{4}$ :Soil application of HA (15 kg/Fed) + Foliar spray of $0.1 \% \mathrm{HA}$

Concerning the effect of applied HA and mineral fertilizers on bulk density and total porosity (Table 2), results indicated that bulk density and total porosity were positively affected by the soil application of HA. A marked decrease in bulk density was occurred at the two rates of soil application of $\mathrm{HA}$ and the decrease was more pronounced at the rate of $30 \mathrm{~kg} \mathrm{HA} / \mathrm{Fed}$. Aggregation resulting from HA must have been the main cause for such a reduction in the bulk density. Similar results were obtained by salib (2003) who found that treating clay soil with HA resulted in a decrease in bulk density. Bulk density is a function of total porosity, therefore, decrease bulk density means increased total porosity. Thus in view of the fact that total porosity is directly deduced from bulk density, any trend of change 
concerning total porosity would be exactly similar to that of bulk density with a reverse direction .

Available $N, P$ and $K$ in soil:

Regarding the affect of applied $\mathrm{HA}$ and mineral fertilizers on the available $\mathrm{N}, \mathrm{P}$ and $\mathrm{K}$, data in Table (3) indicated that available $\mathrm{N}, \mathrm{P}$ and $\mathrm{K}$ increased considerably due to the application of mineral fertilizers and increasing the rate of mineral fertilizers from 75 to $100 \%$ of the recommended dose of fertilizers (RDF) was accompanied by pronounced increases in available $\mathrm{N}, \mathrm{P}$ and $\mathrm{K}$ in soil .

Table (3): Effect of humic acid and NPK fertilizers on available macronutrients (mg/kg soil).

\begin{tabular}{|c|c|c|c|c|c|c|c|c|c|c|c|c|c|}
\hline \multirow{3}{*}{\multicolumn{2}{|c|}{\begin{tabular}{|l} 
Treatments \\
(A) \\
Humic acid \\
\end{tabular}}} & \multicolumn{12}{|c|}{ (B) Fertilizer levels (\% recommended dose of NPK) } \\
\hline & & \multicolumn{4}{|c|}{ Available N } & \multicolumn{4}{|c|}{ Available P } & \multicolumn{4}{|c|}{ Available K } \\
\hline & & 0 & 75 & 100 & Mean & 0 & 75 & 100 & Mean & 0 & 75 & 100 & Mean \\
\hline \multicolumn{2}{|c|}{$\mathrm{H}_{0}$} & 58.1 & 72.5 & 77.3 & 69.3 & 10.1 & 13.0 & 14.2 & 12.4 & 267 & 290 & 304 & 287 \\
\hline \multicolumn{2}{|c|}{$\mathrm{H}_{1}$} & 65.4 & 80.2 & 85.7 & 77.1 & 11.5 & 14.3 & 15.0 & 15.0 & 287 & 308 & 326 & 307 \\
\hline \multicolumn{2}{|c|}{$\mathrm{H}_{2}$} & 70.6 & 86.1 & 92.0 & 82.9 & 12.7 & 15.4 & 16.3 & 16.3 & 309 & 334 & 350 & 331 \\
\hline \multicolumn{2}{|c|}{$\mathrm{H}_{3}$} & 58.6 & 72.4 & 77.5 & 69.5 & 10.3 & 12.9 & 14.1 & 14.1 & 265 & 293 & 308 & 289 \\
\hline \multicolumn{2}{|c|}{$\mathrm{H}_{4}$} & 65.9 & 81.0 & 86.2 & 77.7 & 11.7 & 14.4 & 15.4 & 15.4 & 290 & 315 & 330 & 312 \\
\hline \multicolumn{2}{|c|}{ Mean } & 63.7 & 78.4 & 83.7 & & 11.3 & 14.0 & 15.0 & & 284 & 308 & 324 & \\
\hline \multirow{3}{*}{$\operatorname{LSD}_{0.05}$} & $A$ & \multicolumn{4}{|c|}{4.76} & \multicolumn{4}{|c|}{0.74} & \multicolumn{4}{|c|}{17.4} \\
\hline & $B$ & \multicolumn{4}{|c|}{4.82} & \multicolumn{4}{|c|}{0.85} & \multicolumn{4}{|c|}{18.1} \\
\hline & $\mathrm{AxB}$ & \multicolumn{4}{|c|}{8.15} & \multicolumn{4}{|c|}{ N.S. } & \multicolumn{4}{|c|}{ N.S. } \\
\hline
\end{tabular}

See footnotes of Table 2 for treatment designations.

Soil application of HA was associated with significant increases in available N, P and $\mathrm{K}$. The combined application of HA and mineral fertilizers recorded higher values in respect to $\mathrm{N}, \mathrm{P}$ and $\mathrm{K}$ as compared to the treatments received solely application of mineral fertilizers, and the highest values of available N, P and $\mathrm{K}(92.0,16.3$ and $350 \mathrm{mg} / \mathrm{kg}$ soil, respectively) were obtained under the treatment of $30 \mathrm{~kg} \mathrm{HA} / \mathrm{Fed}$ along with $100 \% \mathrm{RDF}$. Such increase in N, P and $\mathrm{K}$ as a result of $\mathrm{HA}$ addition may be attributed to the improving in soil nutrients retention and enhancing soil microbial activity which works to convert the organic from of nutrients to mineral form (Stevenson,1994). Similar observations were also obtained by Zaky et al.(2006) who mentioned that treated soil with HA through the irrigation water caused marked increases in available $\mathrm{N}, \mathrm{P}$ and $\mathrm{K}$ in soil .

Growth traits:

Data in Table (4) showed that the single application of mineral fertilizers significantly augmented plant hight, number of branches and dry weight of shoot. the more the rate of mineral fertilizers was the more the effect was. The relative increase of plant height, number of branches and dry weight of shoot ( regardless of HA application) were 7.49, 15.0 and $8.99 \%$, respectively with increasing the rate of mineral fertilizers from 75 to 100 RDF.

Regarding HA application, results showed that the treatments receiving HA in both soil or foliar application caused pronounced increases in plant hight, number of branches and dry weight of shoot compared to the untreated ones. This occurred with the two rates of mineral fertilizers. In this 
concern, the highest values of plant hight $(86.5 \mathrm{~cm})$, number of branches (4.00) and dry weight of shoot ( $108 \mathrm{~g} / \mathrm{plant}$ ) were recorded at the rate of $30 \mathrm{~kg} \mathrm{HA} / \mathrm{Fed}$ along with $100 \% \mathrm{RDF}$. Humic acid stimulate plant growth by the assimilation of major and minor elements, enzyme activation and/or inhibition, changes in membrane permeability, protein synthesis and finally the activation of biomass production (Ulukan, 2008) .

In addition, HA can be used as a growth regulator by regulate endogenous hormone levels (Piccolo et al., 1992). These findings are in accordance with those obtained by El-Ghamry et al. (2009) on Faba bean, ElBassiony et al. (2010) on Snap bean and Shehata and El-Helaly (2010) on Snap bean.

Table (4): Effect of humic acid and NPK fertilizers on growth traits of soybean at 90 days age.

\begin{tabular}{|c|c|c|c|c|c|c|c|c|c|c|c|c|}
\hline \multirow{3}{*}{\begin{tabular}{|l|} 
Treatments \\
(A) \\
Humic acid \\
\end{tabular}} & \multicolumn{12}{|c|}{ (B) Fertilizer levels (\% recommended dose of NPK) } \\
\hline & \multicolumn{4}{|c|}{ Plant hight (cm) } & \multicolumn{4}{|c|}{ No. of branches } & \multicolumn{4}{|c|}{$\begin{array}{c}\text { Dry weight of shoot } \\
\text { (g/plant) }\end{array}$} \\
\hline & 0 & 75 & 100 & Mean & 0 & 75 & 100 & Mean & 0 & 75 & 100 & Mean \\
\hline $\mathrm{H}_{0}$ & 51.7 & 67.0 & 72.8 & 63.8 & 2.00 & 2.67 & 3.00 & 2.56 & 54.7 & 82.8 & 90.2 & 75.9 \\
\hline $\mathrm{H}_{1}$ & 60.7 & 74.8 & 80.1 & 71.9 & 2.33 & 3.00 & 3.67 & 3.00 & 66.1 & 92.7 & 100 & 86.3 \\
\hline $\mathrm{H}_{2}$ & 65.3 & 80.4 & 86.5 & 77.4 & 2.67 & 3.33 & 4.00 & 3.33 & 71.0 & 98.1 & 108 & 92.4 \\
\hline $\mathrm{H}_{3}$ & 59.1 & 71.9 & 76.0 & 69.0 & 2.33 & \begin{tabular}{|l|}
3.00 \\
\end{tabular} & 3.33 & \begin{tabular}{|l|}
2.89 \\
\end{tabular} & \begin{tabular}{|l|}
63.9 \\
\end{tabular} & 86.2 & 94.6 & 81.6 \\
\hline $\mathrm{H}_{4}$ & 64.0 & \begin{tabular}{|l|}
77.4 \\
\end{tabular} & 83.2 & \begin{tabular}{|l|l}
74.9 \\
\end{tabular} & \begin{tabular}{|l|}
2.67 \\
\end{tabular} & \begin{tabular}{|l|}
3.33 \\
\end{tabular} & \begin{tabular}{|l|}
3.67 \\
\end{tabular} & \begin{tabular}{|l|}
3.22 \\
\end{tabular} & \begin{tabular}{|l|}
69.2 \\
\end{tabular} & 96.0 & \begin{tabular}{|l|}
104 \\
\end{tabular} & 89.7 \\
\hline Mean & 60.2 & \begin{tabular}{|l|}
74.3 \\
\end{tabular} & \begin{tabular}{|l|}
79.8 \\
\end{tabular} & & 2.40 & \begin{tabular}{|l|}
3.07 \\
\end{tabular} & 3.53 & & \begin{tabular}{|l|}
65.0 \\
\end{tabular} & 91.2 & \begin{tabular}{|l|}
99.4 \\
\end{tabular} & \\
\hline & \multicolumn{4}{|c|}{3.77} & \multicolumn{4}{|c|}{0.28} & \multicolumn{4}{|c|}{5.63} \\
\hline$\mathrm { SD } _ { 0 . 0 5 } \longdiv { \overline { \mathrm { B } } }$ & \multicolumn{4}{|c|}{4.31} & \multirow{2}{*}{\multicolumn{4}{|c|}{0.30}} & \multicolumn{4}{|c|}{6.15} \\
\hline AxB & \multicolumn{4}{|c|}{ N.S. } & \multicolumn{3}{|c|}{0.52} & & \multicolumn{4}{|c|}{10.9} \\
\hline
\end{tabular}

See footnotes of Table 2 for treatment designations.

\section{Nitrogen, $\mathrm{P}$ and $\mathrm{K}$ contents in soybean seeds:}

Date presented in Table (5) showed marked increases in N, P and K concentrations in soybean seeds due to the application of mineral fertilizers and progressed with increasing its rates from 75 to $100 \%$ RFD. Nitrogen, $P$ and $\mathrm{K}$ concentrations increases by $3.68,13.2$ and $5.39 \%$ (irrespective of HA application) respectively with increasing mineral fertilizers rates from $75 \%$ to $100 \%$ RDF.

Humic acid in both soil or foliar application had a significant positive effect on N, P and $\mathrm{K}$ concentrations in soybean seeds and treatments received $\mathrm{HA}$ recorded higher values as compared to those treatments with no HA addition and that occurred under the two applied rates of mineral fertilizers. In this respect, the highest values of $\mathrm{N}, \mathrm{P}$ and $\mathrm{K}$ concentrations (5.62, 0.65 and $1.84 \%$, respectively) were produced by the combined application of $30 \mathrm{~kg} \mathrm{HA} / \mathrm{fed}$ with $100 \%$ RDF. The enhancing affect of HA on $\mathrm{N}, \mathrm{P}$ and $\mathrm{K}$ concentrations may be due to better development root systems (David et al.1994),increased the permeability of plant membranes (Ulukan,2008). Furthermore, humic substances may interact with the phospholipids structures of cell membranes and react as carriers of nutrients through them. These results are in agreement with those obtained by $\mathrm{El}$ Ghamry et al.(2009) who mentioned that foliar application of humic acid (0.1 
and $0.2 \%$ ) caused considerable increases in N,P and $\mathrm{K}$ content in faba bean seeds. Also, Khaled and fawy (2011) reported that applied humic acid in soil application (2 and $4 \mathrm{~g} / \mathrm{kg}$ soil) and foliar spray ( 0.1 and $0.2 \%$ ) significantly increased N, P and K uptake by corn plants.

Table (5): Effect of humic acid and NPK fertilizers on macronutrients concentration in soybean seeds.

\begin{tabular}{|c|c|c|c|c|c|c|c|c|c|c|c|c|}
\hline \multirow{2}{*}{\begin{tabular}{|l|} 
Treatments \\
(A) \\
\end{tabular}} & \multicolumn{12}{|c|}{ (B) Fertilizer levels (\% recommended dose of NPK) } \\
\hline & \multicolumn{4}{|c|}{$\mathbf{N} \%$} & \multicolumn{4}{|c|}{$\mathbf{P} \%$} & \multicolumn{4}{|c|}{$\mathrm{K} \%$} \\
\hline Humic acid & 0 & 75 & 100 & Mean & 0 & 75 & 100 & Mean & 0 & 75 & 100 & Mean \\
\hline $\mathrm{H}_{0}$ & 4.23 & 4.91 & 5.10 & 4.75 & 0.35 & 0.47 & 0.54 & 45 & 1.32 & 1.56 & 1.66 & 1.51 \\
\hline $\mathrm{H}_{1}$ & 4.58 & 5.18 & 5.31 & 5.02 & 0.41 & 0.53 & 0.60 & 0.51 & 1.45 & 1.67 & 1.76 & 1.63 \\
\hline $\mathrm{H}_{2}$ & 4.81 & 5.33 & 5.62 & 5.25 & 0.44 & 0.58 & 0.65 & 56 & 1.55 & 1.77 & 1.84 & 1.72 \\
\hline $\mathrm{H}_{3}$ & 4.54 & 5.09 & 5.24 & 4.96 & 0.39 & 0.50 & $\begin{array}{l}0.57 \\
\end{array}$ & 0.49 & 1.40 & 1.61 & 1.73 & \begin{tabular}{|l|l|}
1.58 \\
\end{tabular} \\
\hline $\mathrm{H}$ & 4.70 & 5.27 & 5.49 & 5.15 & 0.43 & 0.58 & 0.63 & 0.55 & 1.52 & 11.72 & 1.80 & \begin{tabular}{|l}
1.68 \\
\end{tabular} \\
\hline Mean & 4.57 & 5.16 & 5.35 & & \begin{tabular}{|l|}
0.41 \\
\end{tabular} & 0.53 & 0.60 & & 1.45 & \begin{tabular}{|l|}
1.67 \\
\end{tabular} & 1.76 & \\
\hline \multirow{3}{*}{ LSD $_{0.05}$} & \multicolumn{4}{|c|}{0.18} & \multicolumn{4}{|c|}{0.03} & \multicolumn{4}{|c|}{0.28} \\
\hline & \multicolumn{4}{|c|}{0.2} & & \\
\hline & \multicolumn{4}{|c|}{0} & \multicolumn{4}{|c|}{$\frac{0.04}{0.06}$} & & & \\
\hline
\end{tabular}

See footnotes of Table 2 for treatment designations.

\section{Seed yield and yield components:}

Results in Table (6) revealed that the addition of mineral fertilizers significantly increased number of pods plant ${ }^{-1}$, weight of 100 seeds and seed yield. The higher the rate of mineral fertilizers the more pronounced the effect was in increasing all parameters of soybean yield and its components. Values of the relative increase of number of pods plant ${ }^{-1}$, weight of 100 seeds and seed yield (irrespective of $\mathrm{HA}$ application) were 8.56, 3.78 and $6.57 \%$, respectively with increasing mineral fertilizers rate from 75 to $100 \%$ RDF.

Table (6): Effect of humic acid and NPK fertilizers on yield and yield components of soybean.

\begin{tabular}{|c|c|c|c|c|c|c|c|c|c|c|c|c|}
\hline \multirow{2}{*}{\begin{tabular}{|l} 
Treatments \\
(A) \\
\end{tabular}} & \multicolumn{12}{|c|}{ (B) Fertilizer levels (\% recommended dose of NPK) } \\
\hline & \multicolumn{4}{|c|}{ No. of pods plant ${ }^{-1}$} & \multicolumn{4}{|c|}{$\begin{array}{c}\text { Weight of } 100 \text { seeds } \\
(\mathrm{g})\end{array}$} & \multicolumn{4}{|c|}{ Seed yield $(\mathrm{kg} / \mathrm{fed})$} \\
\hline Humic acid & 0 & 75 & 100 & Mean & 0 & 75 & 100 & Mean & 0 & 75 & 100 & Mean \\
\hline $\mathrm{H}_{0}$ & 35.7 & 46.2 & 50.4 & 44.1 & 16.0 & 17.8 & 18.6 & 17.5 & 794 & 1342 & 1472 & \\
\hline $\mathrm{H}_{1}$ & 41.3 & 52.3 & 57.0 & 50.2 & 16.9 & 18.5 & 19.2 & 8.2 & 1053 & 1504 & 1590 & 1382 \\
\hline $\mathrm{H}_{2}$ & 45.9 & 58.0 & 63.2 & 55.7 & 17.5 & 19.1 & 19.7 & 18.8 & 1294 & 1597 & 1694 & 528 \\
\hline $\mathrm{H}_{3}$ & 40.4 & 50.5 & 54.1 & 48.3 & 16.6 & 18.3 & 19.0 & 18.0 & 1010 & 1462 & 1545 & 1339 \\
\hline $\mathrm{H}_{4}$ & 44.0 & 56.2 & 60.8 & 53.7 & 17.2 & 18.8 & 19.5 & \begin{tabular}{|c|}
18.5 \\
\end{tabular} & 1232 & 1553 & 1651 & 1479 \\
\hline Mean & 41.5 & 52.6 & 57.1 & & 16.8 & 18.5 & 19.2 & & 1077 & 1492 & 1590 & \\
\hline \multirow{3}{*}{$\operatorname{LSD}_{0.05}$} & & & .74 & & & & .47 & & & & 0.2 & \\
\hline & & & .91 & & & & .50 & & & & 6 & \\
\hline & & & .56 & & & & I.S. & & & & & \\
\hline
\end{tabular}

See footnotes of Table 2 for treatment designations.

With regard to HA application, results showed that HA in both soil or foliar application significantly enhanced number of pods plant ${ }^{-1}$, weight of 100 seeds and seed yield and such position effect holds true under the two 
applied rates of mineral fertilizers. The combined application of HA and mineral fertilizers gave higher values in respect to the aforementioned parameters compared to the treatments received single application of mineral fertilizers.

In this concern, the greatest values of number of pods plant ${ }^{-1}$ (63.2), weight of 100 seeds $(19.7 \mathrm{~g})$ and seed yield $(1694 \mathrm{~kg} / \mathrm{fed})$ were scored at the rate of $30 \mathrm{~kg} \mathrm{HA} / \mathrm{fed}$ along with $100 \%$ RDF. El-bassiony et al. (2010) found that pod yield of snap bean improved by increasing rates of mineral fertilizers and humic acid as foliar spray and the highest values of pod yield were recorded under the rate of $0.2 \% \mathrm{HA}$ along with $100 \%$ RDF. Similar results were obtained by Zaky et al. (2006) on bean and El-Ghamry et al. (2009) on faba bean.

\section{REFERENCES}

Albuzio, A; G. Concheri; S. Nardi and G. Dell'agnola (1994). Effect of humic fractions of different molecular size on the development of oat seedlings grown on varied nutritional conditions. In: Humic substances in the glabal environment and implications on human health. Eds., $\mathrm{N}$. Senesi and T.M. Mianom. Amsterdam. Elsevier Science, pp: 199-204.

Ayas,H. and F.Gulser (2005). The effects of sulfur and humic acid on yield components and macronutrients content of spinach. Journal of biological Sciences, 5 (b): 801-804.

Black, C.A. (1965). Methods of Soil Analysis. Amer. Soc. of Agronomy, Inc. Pub., Madison, Wisconsin, U.S.A.

Chen, Y. and T. Aviad (1990). Effect of humic substances on plant growth In: Humic substances in soil and crop sciences: Selected readings, Ed., P. Maccarthy, Am. Soc.of Agron. And soil Sci. of Am., Madison, Wisconsin, pp: 161-186.

Cheng, F.J.; D.Q. Yang and Q.S. Wu (1998). Physiological effects of humic acid on drought resistance of wheat. Chinese J. of Applied Ecology, 1995, 6-4, pp: 363-367.

David, P.P.; P.V. Nelson and D.C. Sanders (1994). A humic acid improves growth of tomato seedling in solution culture. J. of plant nutr., $17: 173-$ 184.

El-Bassiony, A.M.; Z.F. Fawzy ; M.M.H. Abd El-Baky and Asmaa, R. Mahmoud (2010). Response of snap bean plants to mineral fertilizers and humic acid application. Res. J. of Agric. and Biolog. Sciences, 6 (2): 169-175.

El-Ghamry, A.M.; K.M. Abd El-Hadi and K.M. Ghoneem (2009 ). Amino and humic acids promote growth, yield and disease resistance of faba bean cultivated in clayey soil. Australian J. of Basic Applied Sciences, 3(2): 731-739.

Frgbenro, J.A. and A.A. Agboola (1993). Effect of different levels of humic acid on growth and nutrients uptake of teak seedlings. J. plant nutrition, 16 (8): 1465-1483. 
Gomez , K.A. and A.Gomez (1984). Statistical procedures for agricultural research, $\left(2{ }^{\text {nd }}\right.$ ed.) pp: $20-29 \& 359-387$.

Jackson, M.L. (1973). Soil Chemical Analysis. Prentice Hall of India Private Limited, New Delhi, India.

Katkat, A.V.; H.celik; M.A. Turan and JB.B. Asik (2009). Effects of soil and foliar application of humic substances on dry weight and mineral uptake of wheat under calcareous soil conditions. Aust. J. of Basic Applied Sciences, 3(2): 1266-1273.

Khaled; H. and H.A.Fawy (2011). Effect of different levels of humic acids on the nutrient content, plant growth and soil properties under conditions of salinity. Soil \& Water Res., 6, 2011 (1): 21-29.

Lobartini, J.C.; G.A. Orioli and K.H. Tan (1997). Characteristics of soil humic acid fractions separated by ultra filtration. Communications in Soil Science and Plant Analysis, 28:787-796.

Nardi, M.R. ; P. Diego; R. Fabiano and A.Muscolo (1999). Biological Activit of humic substances extracted from soils under different vegetation cover Commun.Soil Sci. Plant Anal., 30 (5\&6): 621-634.

Nardi, S.; D. Pizzeghello; A. Muscolo and A. Vianello (2002). Physiological effects of humic substances on higher plants. Soil

Neri, D.; E.M. lodolini; G. Savini ; P. Sabbatini; G. Bonanomi and F. Zucconi (2002) . Foliar application of humic acids on strawberry

Padem, H. and A. Ocal (1999). Effect of humic acid applications on yield and some characteristics of processing tomato. Acta Hort., 487: 159163.

Piccolo, A., S. Nardi and G. Concheri, (1992) . Structural characteristics of humic substances as regulated to nitrate uptake and growth regulation in plant systems. Soil Biochem., 24: 373-380.

Russo, R.O. and G.P. Berlyn, (1990) . The use organic biostimulants to help low input sustainable agriculture. J. of Sust. Agric., 1(2): 19-42.

Salib, M.M.; A.A. Atif and I.M. Michael (2003). Impact of organic and biofertilizers on some physical and chemical properties of clay soil and its productivity of onion bulbs. Egypt. J. Appl. Sci., 18 (3): 382-400.

Sangeetha, M.; P. Singaram and R.D. Devi (2006). Effect of Lignite humic acid and fertilizers on the yield of onion and nutrient availability. In $18^{\text {th }}$ World Congress of Soil Science July 9-15, Philadelphia, Pennsylvania, USA.

Shehata, S.A. and M.A. EL-Helaly (2010). Effect of compost, humic acid and amino acid on yield of snap beans. J. of Hort. Science \& Ornamental Plants 2 (2): 107-110.

Soong, N.K. (1980). Influence of soil organic matter on soil aggregation of soils in Peninsular Malaysia. J.Rubb. Res. Inst. Malaysia, 28: 32-46.

Stevenson, F.J., (1994). Humus Chemistry: Genesis, Composition, Reaction (Second ed.), Wiley and Sons, Inc., New York.

Tajuddin, A. (1992). Influence of organic matter on soil aggregation and erodibility of some Malaysian soils. M. Sc. Agric. Thesis, University

Tan, K.H. (2003). Humic matter in soil and environment. Principles and Controversies, Marcel Dekker, Inc. 270 Madison Avenue, New York. 
Ulukan, H., (2008) . Effect of soil applied humic acid at different sowing times on some yield components in wheat (Triticum spp.) hybrids Int. J. Bot., 4(2): 164-175.

Zaky, M.H.; O.A.H. El-Zeiny and M.E. Ahmed (2006). Effect of Humic acid on growth and productivity of bean plants grown under plastic low tunnels and open field. Egypt. J. of appl. Sci., 21 (4B).

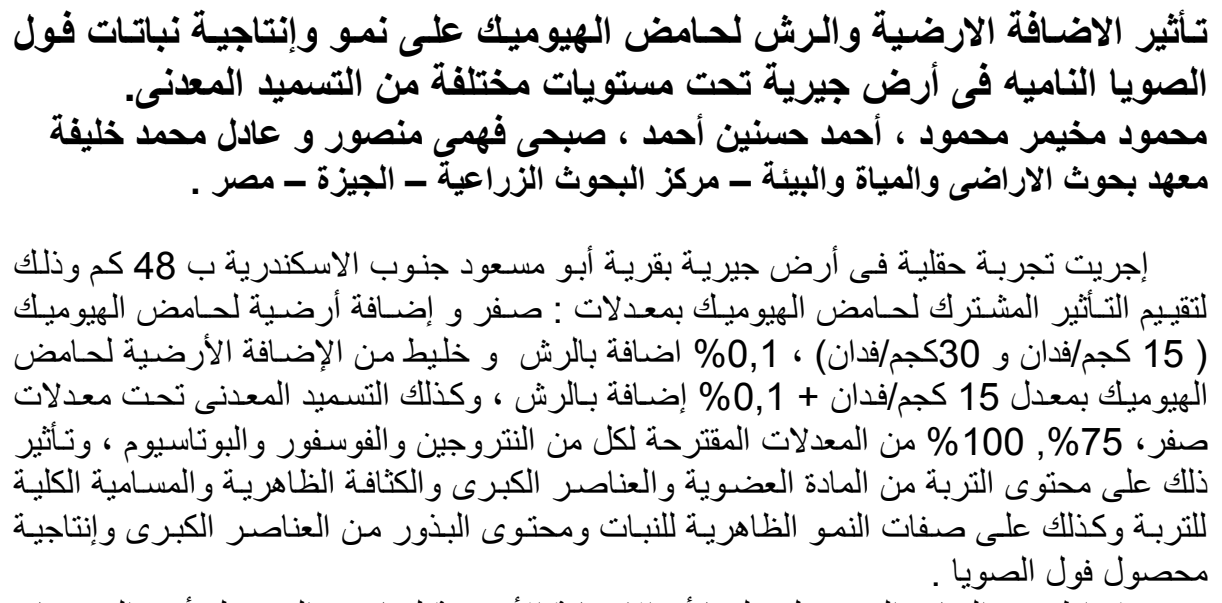

وقد اظهرت النتائج المتحصل عليها أن الإضـافة الأرضية لحامض الهيوميك الدئ أدت إلى زيادة

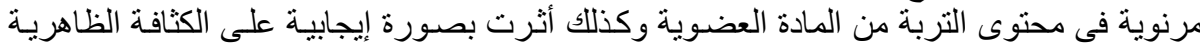

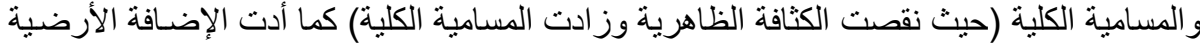

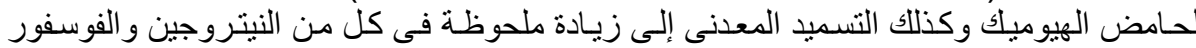



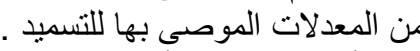

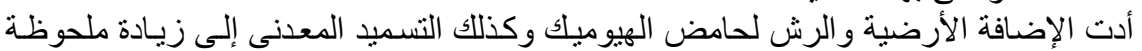

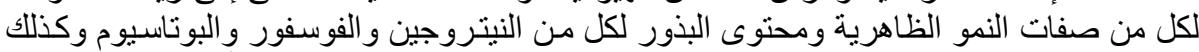

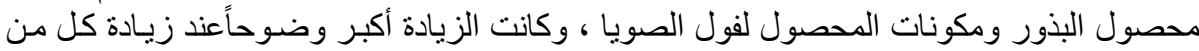

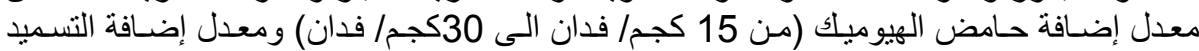

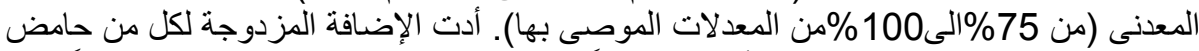

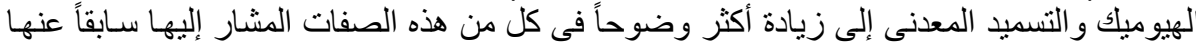

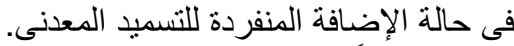

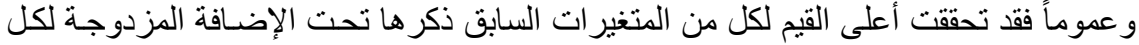
من حامض الهيوميك بمعدل 30كجم/ فدان +100\% من المعدلات المبات الموصى بها للتسميد.

\section{كلية الزراعة - جامعة المنصورة

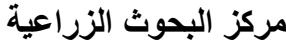

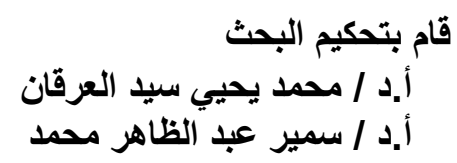

